\title{
EKSPLORASI KANDUNGAN GIZI IKAN SIBERO (Hampala macrolepidota) SEBAGAI BAHAN BAKU DALAM PEMBUATAN PRODUK PANGAN PERIKANAN
}

\author{
Exploration Nutritional Composition of Sibero Fish (Hampala macrolepidota) as Raw \\ Materials In The Production of Fishery Food \\ Ahmad Fauzan Lubis'), Andri Syaputra ${ }^{2)}$ \\ Program Studi Teknologi Pengolahan Hasil Perikanan dan Program Studi Teknik \\ Pendingin \\ Politeknik Tanjungbalai \\ Email: moatre@yahoo.com
}

\begin{abstract}
Sibero fish (Hampala macrolepidota) is a freshwater fish caught by fishermen in the glare river area of Tanjungbalai City. However the number of fish catches is inversely proportional to the sales results. Sibero fish is not a favorite fish for consumption because sibero fish have many bones making it difficult to consume. However, this special processing of sibero fish can become a raw material that is of public interest because sibero fish meat has good nutritional value and tastes good. The purpose of this study was to determine the nutritional content of sibero fish through chemical compositions which include proximate to the proportion of body parts, and increase the potential of sibero fish as food products that have added value through information from the nutritional content. The research method used is the experiment method. The parameter observed was a proximate analysis of the proportion of sibero fish body parts. The results of the study are sibero fish based on the proportion of sibero fish body parts divided into three parts, namely (1) Caput / head section, (2) Truncus / body part, and (3) Cauda / tail section. Comparison of the chemical composition of the proportion of body parts to the content of water content obtained the highest value in the truncus (64.19\%) and the lowest value in the head (57.11\%). The highest ash content in the caput (2.37\%) and the lowest in the cauda (1.90\%). The highest protein in the caput $(18.66 \%)$ and the lowest in the cauda (14.42\%). The highest fat content in the caput $(21.66 \%)$ and the lowest was in cauda (11.87\%). The highest carbohydrate value in the cauda section (8.85\%) and the lowest value in the caput section (0.20\%).
\end{abstract}

Keywords: Sibero Fish, Hampala macrolepidota, nutritional content, proportion, Tanjungbalai

\section{A. PENDAHULUAN}

Kota Tanjungbalai merupakan salah satu kawasan pesisir pantai timur di Propinsi Sumatera Utara yang merupakan daerah pertemuan 2 (dua) sungai besar yaitu Sungai Silau dan Sungai Asahan yang bermuara ke Selat Malaka. Panjangnya sungai yang terdapat di Kota Tanjungbalai memiliki potensi yang sangat besar terhadap bidang perikanan khususnya populasi ikan air tawar. Banyaknya jenis ikan air tawar di kota Tanjungbalai dapat dijadikan alternatif konsumsi jenis ikan laut yang menjadi favorit masyarakat di kota tanjungbalai ini. Salah satu jenis ikan air tawar yang mendominasi di perairan sungai Kota tanjungbalai adalah ikan sibero.

Ikan sibero (Hampala macrolepidota ) merupakan ikan air tawar yang masih banyak terdapat di daerah perairan sungai kota Tanjungbalai. Masih banyaknya populasi ikan sibero di daerah kota Tanjungbalai ini menjadikan ikan yang mendominasi hasil tangkapan masyarakat. Banyaknya hasil tangkapan ikan tersebut tidak berbanding lurus dengan dengan hasil penjualannya. Ikan sibero ini bukanlah ikan favorit yang di konsumsi oleh masyarakat kota Tanjungbalai. Hal ini dikarenakan bahwa ikan sibero diketahui memiliki 
Ahmad Fauzan Lubis, Andri Syahputra / Agrintech | Jurnal Teknologi Pangan dan Hasil Pertanian 3 (1) 2019, 19-27.

tulang yang banyak sehingga susah untuk di konsumsi. Namun dengan pengolahan yang khusus ikan sibero ini dapat menjadi suatu bahan baku perikanan yang baru dan yang diminati masyarakat dikarenakan daging ikan sibero memiliki nilai gizi yang baik dan rasanya enak. Ikan pada umumnya merupakan komoditas yang mempunyai ciri-ciri sangat mudah mengalami kemunduran mutu (perishable, mudah busuk dan rusak; bulky) sehingga perlu upaya untuk mengetahui karakteristik ikan Sibero dari komposisi gizi ikan tersebut dengan yang meliputi proksimat dan asam amino. Informasi tersebut akan bermanfaat dalam pemanfaatan sumber daya ikan Sibero sebagai pemenuhan kebutuhan bahan pangan alternatif masyarakat.

\section{B. METODOLOGI \\ Bahan dan Alat}

Bahan yang digunakan adalah ikan Sibero (Hampala macrolepidota), es batu, aquades, BSA, aquabides, CuSO4, indikator metil merah bromcresol greenmethyl red, K2SO4, larutan H3BO3, larutan $\mathrm{HCl}$, larutan $\mathrm{H} 2 \mathrm{SO} 4$ pekat, larutan $\mathrm{NaOH}$.. Alat yang digunakan adalah neraca analitik, mantel penangas, evaporator, desikator, aluminium foil, beaker glass, corong pisah, ball pipet, autoclave, buret, corong, erlenmeyer, gelas ukur, kantong plastik, labu kjeldahl, mortar dan stamper, pH meter, pipet tetes, pipet pasteur, pipet mohr, pisau, satu set alat LC-MS.

\section{Metode Penelitian}

Metode riset penelitian ini adalah metode expriment. Rancangan yang digunakan adalah Rancangan Acak Lengkap Non Faktorial (RAL) dengan tiga taraf perlakuan terhadap pembagian tiga bagian tubuh yang berbeda (kepala, badan, dan ekor) pada ikan Sibero dengan ulangan sebanyak 3 kali, sehingga terdapat 9 unit percobaan. Parameter yang diamati adalah analisa proksimat meliputi kadar air, kadar abu, protein, lemak, dan karbohidrat dan
Analisa kandungan gizi melalui analisa komposisi asam amino.

Adapun diagram alir dalam penelitian ini dapat dilihat pada gambar 1

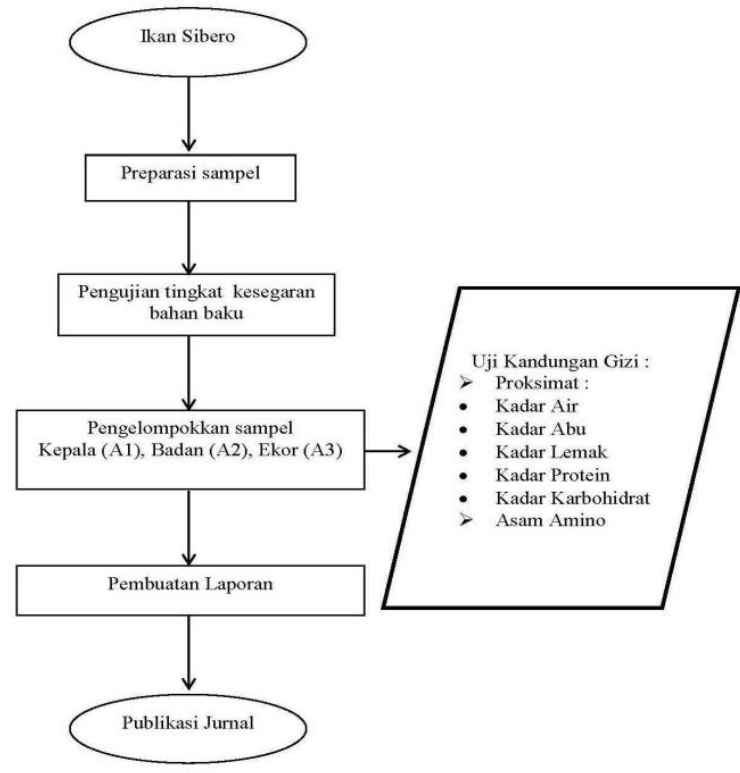

Gambar 1. Alur Proses

\section{HASIL DAN PEMBAHASAN \\ Karakteristik Ikan Sibero}

Ikan Sibero

(Hampala

macrolepidota) yang digunakan dalam penelitian ini adalah Ikan Sibero yang diperoleh dari perairan sungai disekitar Kota Tanjungbalai dengan bobot tubuh 160-240 gram dan panjang tubuh 22-27 cm. Penelitian Makmur et al (2017) menyebutkan bahwa ikan sibero yang telah matang gonad mempunyai ciri-ciri antara lain untuk ikan jantan panjang tubuh 15,38 cm dan ikan betina 19,21 $\mathrm{cm}$. Ukuran ikan sibero sebaiknya yang ditangkap adalah ukuran diatas $20 \mathrm{~cm}$ atau telah dewasa. Bentuk ikan sibero yangdigunakan sebagai bahan baku disajikan pada Gambar 2.

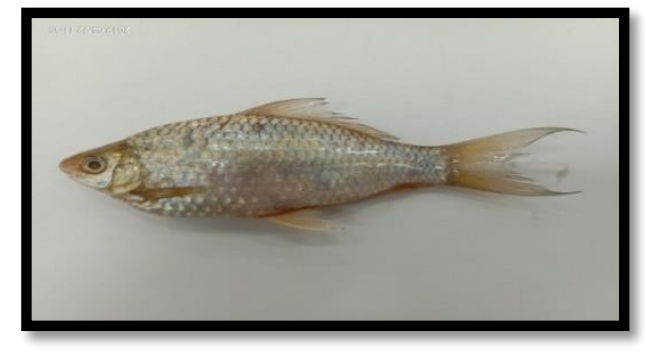

Gambar 2. Ikan Sibero (Hampala macrolepidota)

Ikan Sibero (Hampala macrolepidota) hidup di perairan umum 
Ahmad Fauzan Lubis, Andri Syahputra / Agrintech | Jurnal Teknologi Pangan dan Hasil Pertanian 3 (1) 2019, 19-27.

seperti sungai dan danau (Smith, 1945) yang berair jernih (Inger \& Chin, 1962). Ikan ini terdapat di Indonesia, Malaysia, Muangthai, dan Indo-China (Weber \& de Beaufort, 1916; Smith, 1945; Day, 1967). Ikan Sibero termasuk dalam genus Hampala, sub familia Cyprininae, familia Cyprinidae, sub ordo Cyprinoidea, Ordo Ostariophysi (Weber \& de Beaufort, 1916).

Mulut di ujung, miring, lebar dan melewati pinggiran muka dari mata. Pada rahang atas terdapat dua sungut. Warna keperak-perakan dengan punggung lebih gelap. Pinggiran atas dan bawah sirip ekor berwarna hitam. Antara sirip punggung dan sirip perut berbelang hitam melintang (Weber \& de Beaufort, 1916; Saanin, 1968).

\section{Komposisi Kimia terhadap Proporsi Bagian Tubuh Ikan Sibero}

Proporsi bagian tubuh ikan sibero hamper sama dengan tubuh ikan pada umumnya yang terdiri dari tiga bagian yaitu 1. Caput/bagian pada kepala, 2. Truncus/bagian badan, dan 3 . Cauda/bagian ekor (gambar 3).

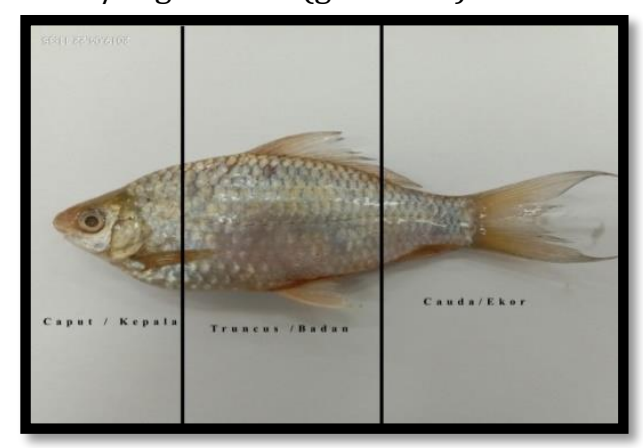

Gambar 3. Proporsi Ikan Sibero

Menurut Anjarsari (2010) tubuh

ikan pada umumnya terbagi atas tiga bagian, yaitu: 1) Caput: bagian kepala, yaitu mulai dari ujung moncong terdepan sampai dengan ujung tutup insang paling belakang. Pada bagian kepala terdapat mulut, rahang atas, rahang bawah, gigi, sungut, hidung, mata, insang, tutup insang, otak, jantung, dan sebagainya. 2) Truncus: bagian badan, yaitu mulai dari ujung tutup insang bagian belakang sampai dengan permulaan sirip dubur. Pada bagian badan terdapat sirip punggung, sirip dada, sirip perut, serta organ-organ dalam seperti hati, empedu, lambung, usus, gonad, gelembung renang, ginjal, limpa, dan sebagainya. 3)
Cauda: bagian ekor, yaitu mulai dari permulaan sirip dubur sampai dengan ujung sirip ekor bagian paling belakang. Pada bagian ekor terdapat anus, sirip dubur, sirip ekor, dan kadang-kadang juga terdapat scute dan finlet.

Proporsi bagian tubuh ikan tersebut pada bagian caput, truncus, dan cauda terdapat proporsi yang berbeda pada komposisi kimianya. Bagian truncus/bagian badan memiliki proporsi yang lebih besar dibandingkan dengan caput ataupun cauda, namun setiap bagian memiliki potensi untuk dapat dijadikan sumber bahan baku yang dapat diolah karena setiap bagian memiliki keunggulan tersendiri dalam komposisi kimianya. Suparjo (2010) menjelaskan bahwa analisis proksimat memiliki beberapa keunggulan yakni merupakan metode umum yang digunakan untuk mengetahui komposisi kimia suatu bahan pangan, tidak membutuhkan teknologi yang canggih dalam pengujiannya, menghasilkan hasil analisis secara garis besar, dapat menghitung nilai total digestible nutrient dan dapat memberikan penilaian secara umum pemanfaatan dari suatu bahan pangan. Hasil analisis proksimat proporsi bagian tubuh ikan sibero disajikan pada Tabel 1 berikut:

Tabel 1. Hasil proksimat proposi bagian tubuh Ikan Sibero (Hampala macrolepidota)

\begin{tabular}{lllll}
\hline \multirow{2}{N}{} & \multirow{2}{*}{ Jenis } & \multicolumn{3}{c}{ Hasil (\%) } \\
$\mathrm{o}$ & Analisa & Kepal & Bada & Ekor \\
& $\mathrm{a}$ & $\mathrm{n}$ & \\
\hline 1 & Kadar Air & 57,11 & 64,1 & 62,9 \\
& & \pm & $9 \pm$ & $6 \quad \pm$ \\
& & 0,25 & 0,10 & 0,03 \\
2 & Kadar Abu & 2,37 & 1,96 & 1,90 \\
& & \pm & \pm & \pm \\
& & 0,27 & 0,03 & 0,00 \\
3 & Protein & 18,66 & 17,4 & 14,4 \\
& & \pm & $7 \pm \pm$ & 2 \\
& & 0,03 & 0,07 & 0,03 \\
4 & Lemak & 21,66 & 16,1 & 11,8 \\
& & \pm & $3 \pm$ & 7 \\
& & 0,01 & 0,01 & 0,04 \\
5 & Karbohidr & 0,20 & 0,25 & 8,85 \\
& at & \pm & \pm & \pm \\
& & 0,00 & 0,01 & 0,04 \\
\hline
\end{tabular}

Kadar air merupakan banyaknya air yang terkandung dalam bahan yang sangat dibutuhkan untuk proses 
pencernaan dan metabolisme. Pada gambar 4 kadar Air menunjukkan variasi dan di pengaruhi oleh perbedaan proposi bagian tubuh $(\mathrm{P}<0,05)$. Hasil pengujian komposisi kimia terhadap kadar air didapatkan nilai tertinggi pada bagian truncus/badan yaitu 64,19\% dan nilai terendah pada bagian caput/kepala yaitu 57,11\%. Air merupakan komponen dasar ikan. Air di dalam daging ikan terdapat dua bentuk yaitu air bebas dan air terikat sangat sukar dihilangkan dari daging ikan maupun dengan cara pengeringan. Menurut Suwedja (2011), kadar air ikan sangat bervariasi, baik antar jenis yang satu dengan yang lain, antara individu dalam jenis dan bahkan antar bagianbagian tubuh dalam satu individu.

Salam et al. (2001) menyatakan panjang total tubuh ikan berbanding lurus dengan kandungan bahan organik di dalam tubuh ikan, sedangkan kandungan bahan organik akan berbading terbalik dengan kadar airnya. Pertambahan ukuran tubuh ikan akan menyebabkan penurunan kadar air, karena semakin bertambahnya kandungan bahan organik di dalam tubuh ikan.

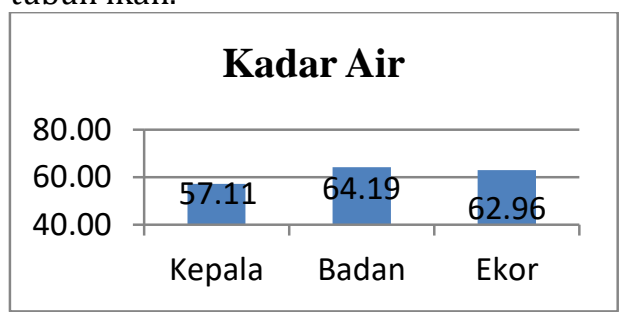

Gambar 4. Kadar air proporsi bagian tubuh ikan sibero

Kadar air dalam bahan makanan sangat mempengaruhi kualitas dan daya simpan dari pangan tersebut. Oleh karena itu, penentuan kadar air dari suatu bahan pangan sangat penting agar dalam proses pengolahan maupun pendistribusian mendapat penanganan yang tepat. Bahan pangan dengan kadar air yang tinggi apabila tidak ditangani dengan benar akan cepat mengalami kemunduran mutu oleh aktivitas bakteri dan enzim (Ilyas, 1983).

Abu adalah zat anorganik sisa hasil pembakaran suatu bahan organik. Kadar abu menunjukkan kadar mineral yang terdapat dalam suatu bahan. Proses metabolisme berperan dalam pembentukan mineral tubuh. Pengabuan dilakukan untuk menentukan jumlah mineral yang terkandung dalam bahan. Penentuan kadar mineral bahan secara asli sangatlah sulit sehingga perlu dilakukan dengan menentukan sisa hasil pembakaran atas garam mineral bahan tersebut. Pengabuan dapat menyebabkan hilangnya bahan-bahan organik dan anorganik sehingga terjadi perubahan radikal organik dan terbentuk elemen logam dalam bentuk oksida atau bersenyawa dengan ion-ion negatif (Sudarmadji et al., 2007).

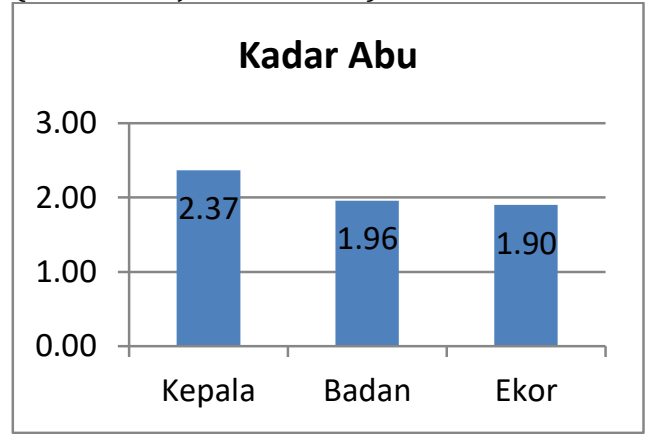

Gambar 5. Kadar abu proporsi bagian tubuh ikan sibero

Hasil pengujian komposisi kimia terhadap kadar abu tidak terlalu berbeda antara proporsi bagian tubuh ikan $(\mathrm{P}>0,05)$, hal ini karena Kadar abu ada hubungannya dengan mineral suatu bahan. Perbedaan kadar abu tersebut dipengaruhi oleh habitat hidup ikan sibero. Kandungan abu pada ikan bergantung pada habitat hidup ikan tersebut yang berhubungan dengan kandungan mineral yang terdapat dalam tubuh ikan (Tsaniyatul et al. 2013). Dari hasil penelitian didapatkan nilai kadar abu tertinggi pada bagian caput yaitu $2,37 \%$ dan terendah pada truncus yaitu $1,90 \%$ (gambar 5). Penentuan abu total dilakukan dengan tujuan untuk menentukan baik tidaknya suatu proses pengolahan, mengetahui jenis bahan yang digunakan, serta dijadikan parameter nilai gizi bahan makanan.

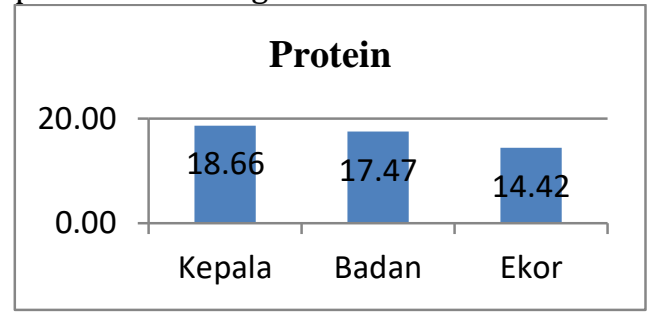

Gambar 6. Protein proporsi bagian tubuh ikan sibero 
Hasil pengujian komposisi kimia terhadap kandungan protein didapatkan perbedaan yang signifikan anatar proporsi bagian tubuh ikan sibero $(\mathrm{P}<0,05)$. nilai tertinggi pada bagian truncus yaitu $15,97 \%$ dan nilai terendah pada bagian caput yaitu $14,65 \%$ (gambar 6).

Protein berperan penting untuk pertumbuhan, karena mengandung asam amino esensial dan non-esensial. Protein merupakan sumber energi utama pada ikan, jika kebutuhan protein tidak dicukupi dalam makanannya, maka akan terjadi penurunan drastis atau penghentian pertumbuhan atau kehilangan bobot tubuh karena ikan akan menarik kembali protein dari beberapa jaringan untuk mempertahankan fungsi dari jaringan yang lebih vital (Iskandar, 2017).

Lemak adalah bentuk energi berlebih yang disimpan oleh hewan sehingga jumlah lemak dalam hewan yang dijadikan bahan pangan ditentukan oleh keseimbangan energi hewan tersebut (Belitz et al. 2009). Lemak secara kimiawi tersusun oleh sekelompok senyawa yang berbeda dalam bahan makanan lemak dapat terdiri dari dua bentuk yaitu yang tampak (visible) dan yang tidak tampak (invisible). Lemak yang tampak misalnya mentega, margarin, minyak goreng dan sebagainya. Lemak yang tidak tampak misalnya yang terdapat dalam berbagai bahan makanan seperti daging, kacang tanah, susu, telur, dan sebagainya (Sediaoetama, 2008).

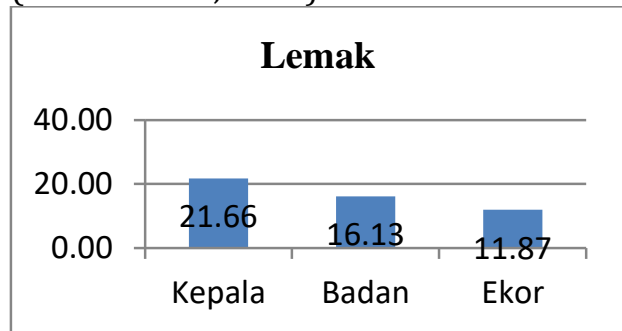

Gambar 7. Lemak proporsi bagian tubuh ikan sibero

Hasil pengujian komposisi kimia terhadap kandungan lemak didapatkan perbedaan antara proporsi bagian tubuh ikan $(\mathrm{P}<0,05)$ dengan nilai tertinggi pada bagian caput/kepala yaitu $21,66 \%$ dan nilai terendah pada bagian cauda yaitu 11,87\% (gambar 7). Lemak juga dapat digunakan sebagai sumber asam lemak esensial dan vitamin (vitamin A, D, E dan K) (Belitz et al. 2009).

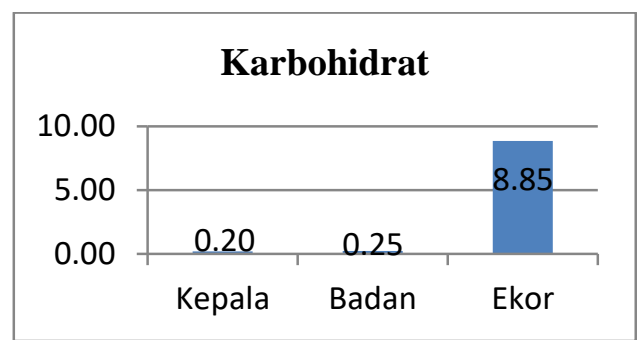

Gambar 8. Karbohidrat proporsi bagian tubuh ikan sibero

Hasil pengujian komposisi kimia terhadap kandungan karbohidrat didapatkan nilai tertinggi pada bagian cauda/ekor yaitu $8,85 \%$ dan nilai terendah pada bagian caput/kepala yaitu $0,20 \%$ (gambar 8). Kandungan karbohidrat meningkat diakibatkan oleh menurunnya kadar protein, lemak, dan abu pada daging ikan (Yulindra et al. 2013).

Kandungan Asam Amino pada Ikan Sibero

Senyawa organik yang berperan sebagai komponen penyusun protein adalah asam amino. Asam amino memiliki beberapa fungsi diantaranya yaitu sebagai penyusun protein, termasuk enzim dan sebagai kerangka dasar sejumlah senyawa penting dalam metabolisme (terutama vitamin, hormon, dan asam nukleat). Mutu suatu protein ditentukan oleh jenis dan proporsi asam amino yang dikandungnya. Protein yang bermutu adalah protein yang dapat menyediakan asam amino esensial dalam perbandingan yang menyamai kebutuhan tubuh (Winarno, 1997). Analisis asam amino dilakukan untuk menduga kandungan asam amino pada protein ikan sibero segar.

Hasil dari analisis asam amino ikan sibero segar didapatkan 17 asam amino yang terdiri dari 9 jenis asam amino esensial dan 8 jenis asam amino nonesensial. Asam amino esensial yang terdapat pada ikan sibero adalah histidin, arginin, treonin, valin, metionin, isoleusin, leusin, fenilalanin dan lisin. Asam amino non esensial yang terkandung dalam ikan sibero adalah asam aspartat. asam glutamat, serin, glisin, alanine, prolin, tirosin dan sistein. Hasil analisis asam amino ikan sibero 
Ahmad Fauzan Lubis, Andri Syahputra / Agrintech | Jurnal Teknologi Pangan dan Hasil Pertanian 3 (1) 2019, 19-27.

dalam keadaan segar dapat dilihat pada Tabel 2.

Asam amino dibagi menjadi dua, yaitu asam amino esensial dan asam amino non esensial. Asam amino esensial merupakan asam amino yang tidak dapat dibentuk oleh tubuh manusia (nutritive food) dan asam amino non esensial merupakan asam amino yang dapat dibentuk oleh tubuh manusia (Winarno, 2004).

Tabel 2. Kandungan asam amino Ikan Sibero

\begin{tabular}{|c|c|c|}
\hline No & $\begin{array}{ll}\text { Jenis } & \text { Asam } \\
\text { Amino } & \\
\end{array}$ & $\begin{array}{l}\text { Kadar Asam } \\
\text { Amino (\%) }\end{array}$ \\
\hline 1 & Histidin & 0.716 \\
\hline 2 & Arginin & 1.058 \\
\hline 3 & Treonin & 0.825 \\
\hline 4 & Valin & 1.371 \\
\hline 5 & Metionin & 0.544 \\
\hline 6 & Isoleusin & 1.412 \\
\hline 7 & Leusin & 2.632 \\
\hline 8 & Fenilalanin & 1.268 \\
\hline 9 & Lisin & 2.901 \\
\hline 10 & Asam aspartat & 1.924 \\
\hline 11 & Asam glutamat & 4.835 \\
\hline 12 & Serin & 0.939 \\
\hline 13 & Glisin & 2.204 \\
\hline 14 & Alanin & 0.629 \\
\hline 15 & Prolin & 2.815 \\
\hline 16 & Tirosin & 1.596 \\
\hline 17 & Sistein & 0.477 \\
\hline
\end{tabular}

Pada tabel menunjukkan bahwa diantara 17 asam amino yang dihasilkan dalam penelitian didominasi oleh dua jenis asam amino esensial, yaitu lisin dan leusin, sedangkan untuk asam amino non esensial didominasi oleh tiga jenis asam amino, yaitu glutamat, prolin dan glisin. Penelitian Suryanti (2009) menyatakan bahwa dari 15 asam amino dalam daging patin, terdapat empat jenis asam amino esensial yang mendominasi, yaitu treonin, leusin, lisin dan valin, sedangkan untuk asam amino non esensial terdapat empat jenis yang mendominasi yaitu, aspartat, glutamat, glisin dan alanin. Hasil analisis asam amino terhadap daging patin segar menunjukkan variasi komposisi kimia dapat terjadi antar spesies, antar individu dalam suatu spesies, antar individu dalam suatu spesies dan antara bagian tubuh satu dengan yang lain (Suzuki 1981 dalam Nurjanah et al. 2009).
1. Asam Amino Esensial

Asam amino esensial merupak: asam amino yang tidak dapat disintes di dalam tubuh sehingga harus diasup melalui makanan. Asam amino esensial memiliki peranan yang penting dalam keseimbangan tubuh. Hasil analisis menggunakan HPLC, terdekteksi 9 jenis asam amino esensial, yaitu histidin, arginin, treonin, valin, metionin, isoleusin, leusin, fenilalanin dan lisin. Histogram kandungan asam amino esensial pada ikan sibero dapat dilihat pada gambar 8 .

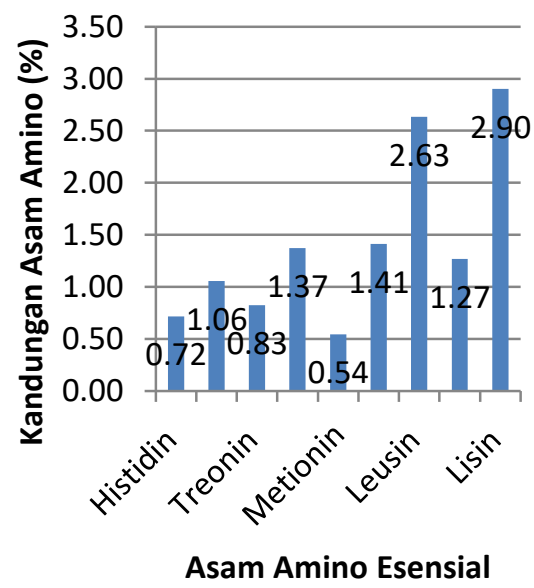

Gambar 9. Kandungan asam amino esensial ikan sibero

Gambar 9 menunjukkan bahwa asam amino esensial yang memiliki nilai tertinggi pada ikan sibero adalah lisin dengan nilai 2,9\%. Lisin merupakan asam amino yang berfungsi sebagai bahan dasar antibodi darah, memperkuat sistem sirkulasi, mempertahankan pertumbuhan sel-sel normal bersama prolin dan vitamin $\mathrm{C}$ akan membentuk jaringan kolagen, menurunkan kadar trigliserida darah yang berlebih. Kekurangan lisin dapat menyebabkan mudah lelah, sulit konsentrasi, rambut rontok, anemia, pertumbuhan terhambat dan kelainan reproduksi (Edison, 2009).

Lisin tergolong esensial bagi manusia dan kebutuhan rata-rata per hari adalah (1,0-1,5) g. Lisin menjadi kerangka dalam pembentukan niasin (Vitamin B3), bahan dasar antibodi darah, memperkuat sistem sirkulasi, dan mempertahankan pertumbuhan sel-sel normal. Kekurangan lisin menyebabkan mudah lelah, sulit konsentrasi, rambut 
Kandungan lisin pada daging patin segar cukup tinggi, sehingga daging ikan sibero dapat dijadikan sebagai sumber asam amino esensial yang menunjang pertumbuhan.

Semakin tinggi kadar asam amino esensial dalam suatu bahan pangan, semakin baik pula mutu protein bahan pangan tersebut (Winarno 1997). FAO/WHO (1985) dalam Wu et al. (2010) menetapkan kebutuhan asam amino untuk anak-anak usia 2-5 tahun lebih dari $100 \mathrm{mg}$ asam amino/kg berat badan yang digunakan untuk pertumbuhan anak-anak. Perbedaan kandungan asam amino dipengaruhi oleh beberapa faktor diantaranya musim, ukuran tubuh, tahap kedewasaan, suhu lingkungan dan ketersediaan bahan makanan (Sudhakar et al. 2009)

\section{Asam Amino Non Esensial}

Asam amino non esensial merupakan asam amino yang dapat disintesis di dalam tubuh. Hasil analisis terdeteksi 8 jenis asam amino non esensial, yaitu asam aspartat. asam glutamat, serin, glisin, alanine, prolin, tirosin dan sistein. Asam amino non esensial yang terdapat pada ikan sibero disajikan pada Gambar 10. Pada gambar menunjukkan bahwa asam amino non esensial yang memiliki nilai tertinggi pada daging sibero adalah glutamat dengan nilai 4,84\%. Asam glutamat mengandung ion glutamat yang dapat merangsang beberapa tipe syaraf yang ada pada lidah manusia. Asam glutamat dan asam aspartat memberikan cita rasa pada seafood, namun dalam bentuk garam sodium seperti pada MSG akan memberikan rasa umami (Uju et al 2009).

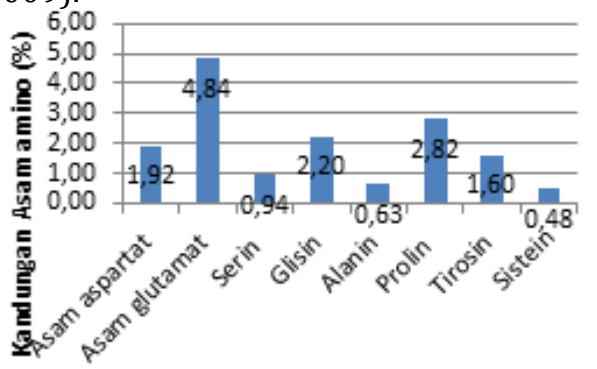

Asam Amino Non Esensial

Gambar 10. Kandungan asam amino non esensial ikan sibero bahan makanan yang mengandung protein yang tinggi misalnya daging, ikan, susu dan sayur-sayuran. Glutamat juga dapat diproduksi dalam tubuh manusia dan merupakan komponen yang sangat penting bagi metabolisme manusia. Glutamat memiliki ciri bila ditambahkan ke dalam suatu bahan pangan akan memberikan ciri rasa yang kuat dan merangsang saraf yang ada pada lidah manusia. Sifat ini dimanfaatkan oleh industri penyedap. Garam turunan yang berasal dari glutamat, yang dikenal sebagai monosodium glutamat sangat dikenal sebagai penyedap makanan masakan (Ardyanto 2004). Kandungan asam glutamat memiliki porsi tertinggi pada daging patin, sehingga dalam proses pemasakan patin tidak perlu dilakukan penambahan penyedap masakan (monosodium glutamat/MSG). Tingginya asam glutamat pada daging patin menyebabkan dagingnya beraroma gurih dan berasa manis (Nurjanah et al. 2009). Asam glutamat merupakan komponen paling penting dalam pembentukan cita rasa pada makanan hasil laut dan perairan pada umumnya sehingga makanan terlihat gurih. Kandungan asam glutamat cukup signifikan dan tergolong cukup besar. Tingginya kandungan asam glutamat pada ikan sibero segar disebabkan karena proses analisis yang menggunakan hidrolisis asam yang mempunyai derajat analisis yang lebih tinggi (Derby et al. 2007).

\section{KESIMPULAN}

Ikan sibero bukan ikan favorit untuk di konsumsi oleh masyarakat. Hal ini dikarenakan bahwa ikan sibero diketahui memiliki tulang yang banyak sehingga susah untuk di konsumsi. Namun dengan pengolahan yang khusus ikan sibero ini dapat menjadi suatu bahan baku perikanan yang baru dan yang diminati masyarakat dikarenakan daging ikan sibero memiliki zat gizi yang baik dan rasanya enak. Zat gizi utama pada ikan antara lain protein, lemak, vitamin dan mineral. Adapun hasil pengkajian yang dilakukan yaitu ikan 
Ahmad Fauzan Lubis, Andri Syahputra / Agrintech | Jurnal Teknologi Pangan dan Hasil Pertanian 3 (1) 2019, 19-27.

sibero berdasarkan proporsi bagian tubuh ikan sibero seperti pada tubuh ikan umumnya terbagi tiga bagian yaitu 1. Caput/bagian pada kepala, 2. Truncus/bagian badan, dan 3 . Cauda/bagian ekor.

Perbadingan proporsi bagian tubuh pada komposisi kimia terhadap kandungan kadar air didapatkan nilai tertinggi pada bagian truncus yaitu $64,19 \%$ dan nilai terendah pada bagian caput yaitu $57,11 \%$. Kadar abu didapatkan nilai tertinggi pada bagian caput yaitu $2,37 \%$ dan nilai terendah pada bagian cauda yaitu $1,90 \%$. Kandungan Protein didapatkan nilai tertinggi pada bagian caput yaitu $18,66 \%$ dan nilai terendah pada bagian cauda yaitu 14,42\%. Kandungan Lemak didapatkan nilai tertinggi pada bagian caput yaitu $21,66 \%$ dan nilai terendah pada bagian cauda yaitu $11,87 \%$. Karbohidrat didapatkan nilai tertinggi pada bagian cauda yaitu $8,85 \%$ dan nilai terendah pada bagian caput yaitu $0,20 \%$.

\section{UCAPAN TERIMAKASIH}

Karya ini didukung secara finansial oleh Kementerian Riset, Teknologi, dan Pendidikan Tinggi Republik Indonesia melalui Penelitian Dosen Pemula (PDP) 2019. Para penulis berterima kasih kepada seluruh civitas akademika Program Studi Teknologi Pengolahan Hasil Perikanan Politeknik Tanjungbalai.

\section{DAFTAR PUSTAKA}

Anjarsari B. 2010. Pangan Hewani Fisiologi Pasca Mortem dan Teknologi.Yogyakarta (ID): Penerbit Graha Ilmu

Ardyanto TD. 2004. MSG dan kesehatan: sejarah, efek dan kontroversinya. http://www.inovasionline.com. [21 Agustus 2019]

Belitz HD, Grosch W, Schieberle P. 2009. Food Chemistry. Ed rev ke-4. Verlag: Springer

Day JH. 1967. A Monograph on the Polychaete of Southern Africa. Part 1 \& 2. Trustees. London:
The British Museum (Natural History).

Derby CD, Kicklighter CE, Jhonson PM, Zang X. 2007. Chemical Composition of Inks of Diverse Marine Molluscs Suggests Convergent Chemical Defenses. Journal J chem ecol. Vol (33):1105-1113

Edison T. 2009. Amino acid: Esensial for our bodies. http://livewellnaturally.com. [21 Agustus 2019]

Harli M. 2008. Asam amino esensial. http://www.supamas.com . [21 Agustus 2019].

Ilyas. 1983. Teknologi Refrigerasi Hasil Perikanan. CV. Paripurna. Jakarta.

Inger RF, and Chin PK. 1962. Fieldiana Zoology. The Freshwater Fishes of North Borneo. 45:1-268.

Iskandar, Rina dan Fitriadi, S. 2017. Analisa Proksimat Pakan Hasil Olahan Pembudidaya Ikan di Kabupaten Banjar Kalimantan Selatan. Jurnal Ziraa'ah, 42(1), 65-68.

Makmur S, Mutmainnah D, Subagdja. (2017). Pengelolaan ikan hampal (hampala macrolepidota kuhl \& Van hasselt 1823) di danau ranau, Sumatera selatan dan lampung, Jurnal Kebijakan Perikanan Indonesia. Vol. 9 No. 2. 61-70.

Nurjanah D, Ariyanti, Nurhayati T, Abdullah A. 2009. Karakteristik daging rajungan (Portunus pelagicus) industry rumah tangga, Desa Gegunung Wetan Rembang Jawa Tengah. Di dalam: Seminar Nasional Perikanan Indonesia 2009. Sekolah Tinggi Perikanan, Desember 3-4, 2009.

Saanin H. 1968. Taksonomi dan Kunci Identifikasi Ikan. PT Bina Cipta. Bandung.

Salam A, Ali M, Anas M. 2001. Body composition of Oreochromis mossambicus in relation to body size and condition factor. Journal of Research (Science), Bahauddin Zakariya University, Multan, Pakistan. 12(1):89-96. 
Ahmad Fauzan Lubis, Andri Syahputra / Agrintech | Jurnal Teknologi Pangan dan Hasil Pertanian 3 (1) 2019, 19-27.

Smith. 1945. The fresh water fishes of Siam or Thailand Smithsonian. United States National Museum Bulletin Washington. USA. 57-59 $p$.

Sudarmadji S, dkk. 2007. Prosedur Analisis Untuk Bahan Makan Dan Pertanian. Liberty. Yogyakarta

Sudhakar M, Manivannan K and Soundrapandian P. 2009. Nutritive value of hard and soft shell crabs of Portunus sanguinolentus (herbst). J. of Animal and Veterinary Advances 1(2):44-48.

Suparjo, P. 2010. Reposisi Tanaman Pakan dalam Kurikulum Fakultas Peternakan. Lokakarya Nasional Tanaman Pakan Ternak.

Suryanti. 2009. Kajian sifat fungsional daging lumat dan surimi ikan patin siam (Pangasius hypopthalmus) serta aplikasinya menjadi dendeng giling dan pendugaan umur simpannya [tesis]. Sekolah Pascasarjara, Institut Pertanian Bogor.

Suwedja. 2011. Biokimia Hasil Perikanan. Jakarta: Media Prima Aksara

Tsaniyatul SMS, Dwi TS, Suprayitno E. 2013. Pengaruh suhu pengukuran terhadap kandungan gizi dan organoleptik abon ikan gabus (Ophiocephalus
W, Siburian M. 2009.

Karakterisasi dan recovery protein dari air cucian minced fish dengan membrane resrved osmosis. Jurnal Pengolahan Hasil Perikanan 12(2):115-127.

Weber M, and LF de Beaufort. 1916. The Fishes of the Indo-Australian Archipelago III. Ostariophysi: II Cyprinoidea, Apodes. Synbranchii. Brill, Leiden.

Winarno, F. G. 1997. Kimia Pangan dan Gizi. Gramedia Pustaka Utama. Jakarta.

Winarno, F. G. (2004). Kimia Pangan dan Gizi. Cetakan Kesebelas. PT. Gramedia Pustaka Utama. Jakarta

Wu X, Zhou B, Cheng Y, Zeng C, Wang C, Feng L. 2010. Comparison of gender differences in biochemical composition and nutritional value of various edible parts of the blue swimmer crab. J. of Food Composition and Analysis 23:154-159.

Yulindra T, Dwi TS, Suprayitno E. 2013. Pengaruh konsentrasi residu daging ekstraksi albumin ikan gabus (Ophiocephalus striatus) yang berbeda terhadap kualitas sosis ikan. THPi Student Journal 1(2): 51-60. 